\title{
TINJAUAN EKOTEOLOGI RELASI MANUSIA DAN ALAM DALAM TRADISI SESUCI DIRI DI CANDI JOLOTUNDO MOJOKERTO
}

\author{
Anugerah Zakya Rafsanjani \\ Pascasarjana Universitas Islam Negeri Sunan Ampel Surabaya, Indonesia \\ E-mail: zanugerah@gmail.com
}

\begin{abstract}
This article analyzes about relation between human and nature in the "self-cleansing" tradition and knows the meaning of purity in the ecotourism perspective in the Seloliman village of Mojokerto. The purpose of this study is to understand human and natural relations in a tradition as self-serving and to know the meaning of self as purely in the ecotourism perspective. The results of this study concluded that, in the perspective of Javanese philosophy, a purely self-made tradition was used to draw closer to God, especially in the silent procession. The process of silence is the stage where a person performs self-reflection and reaches harmony with God and nature. In the perspective of existentialistic phenomenology, the ability to understand Jolotundo as a space for spiritual practice provides an understanding of spiritual actors in their interests in this world, and their ontological relations with nature and their world. In the ecotourism perspective, as self-serving has undergone cultural acculturation in each method and its meaning, this indicates that every religion that is acculturated in a purified tradition has a universal meaning about the existence of nature.
\end{abstract}

Keywords: Human; nature; self-cleansing; ecotology; Jolotundo.

\begin{abstract}
Abstrak: Artikel ini menganalisis tentang relasi manusia dan alam dalam tradisi "sesuci diri" dan mengetahui makna sesuci diri dalam perspektif ekoteologi di Desa Seloliman Mojokerto. Adapun tujuan dalam penelitian ini yaitu memahami relasi manusia dan alam dalam tradisi sesuci diri dan mengetahui makna sesuci diri dalam perspektif ekoteologi. Hasil penelitian ini menyimpulkan bahwa, dalam perspektif falsafah Jawa, tradisi sesuci diri dilakukan guna mendekatkan diri terhadap Tuhan, terutama dalam prosesi hening. Proses hening merupakan tahap seseorang melakukan refleksi diri serta mencapai harmoni dengan Tuhan dan alam. Dalam perspektif fenomenologi eksistensialistik, kemampuan memahami Jolotundo sebagai ruang laku spiritual memberikan pemahaman terhadap pelaku spiritual akan kepentingannya dalam dunia ini, dan relasi ontologisnya dengan alam dan dunianya. Dalam perspektif ekoteologi, sesuci diri telah mengalami akulturasi budaya dalam setiap metode dan maknanya, hal ini menandakan bahwa setiap agama yang terakulturasi dalam tradisi sesuci diri mempunyai makna universal tentang eksistensi alam.
\end{abstract}

Kata Kunci: Manusia; Alam; Sesuci Diri; Ekoteologi; Jolotundo. 


\section{Pendahuluan}

Mojokerto adalah salah satu kota yang memiliki banyak warisan sejarah, banyaknya temuan prasasti, candi dan artefak-artefak kerajaan masa lalu mendukung hal itu. Hal ini tidak mengherankan karena Mojokerto merupakan salah satu daerah kekuasaan kerajaan Medang (Mataram Kuno) yang dipimpin oleh Mpu Sindok setelah dia memindahkan pemerintahan Kerajaan Medang dari Jawa Tengah ke Jawa Timur, ${ }^{1}$ kemudian Mojokerto menjadi salah satu wilayah kekuasaan Kerajaan Kahuripan yang dipimpin oleh Airlangga dan pusat pemerintahan kerajaan Majapahit. Peralihan dominasi dari kerajaan satu ke kerajaan lainnya menjadikan Mojokerto selalu menarik untuk dikaji secara historis, arkeologis, dan antropologis.

Fase akhir Majapahit menyaksikan peningkatan pembangunan tempat suci di gunung. Kemungkinan penyebab dan faktor di balik perkembangan ini telah banyak dibahas dari sudut pandang politik, sosial serta agama. Setelah masa kejayaan Majapahit di bawah pemerintahan Hayam Wuruk pada abad ke 14, abad ke 15 menyaksikan kemerosotan kekuasaan politik Majapahit. Pada akhir abad ke 14, Majapahit diguncang pertikaian internal. ${ }^{2}$

Menurut Hariani Santiko (1990, 1998) dan Agus Munandar (1990) yang dikutip oleh Lydia Kieven dalam bukunya Following the Cap-Figure in Majapabit Temple Reliefs, menjelaskan bahwa, komunitas resi sudah menjadi faktor penting dalam kehidupan beragama sejak zaman Airlangga, malah memainkan peran yang semakin menonjol dalam keagamaan pada era Majapahit. Tempat untuk praktik bertapa, ritual dan pengajaran pengetahuan esoteris adalah pertapaan yang terletak di daerah terpencil, biasanya di lereng gunung. ${ }^{3}$

Umumnya tempat-tempat suci seperti candi yang berada di lerenglereng gunung dan tempat lainnya tidak bisa dilepaskan dari adanya kolam air. Air selalu memiliki peran penting dalam keberadaan setiap candi, dengan kualitasnya melindungi kehidupan, menyuburkan dan menyucikan, air memiliki berbagai makna simbolis dalam mitologi Jawa klasik.

\footnotetext{
1 Slamet Muljana, Menuju Puncak Kemegahan: Sejarah Kerajaan Majapabit (Yogyakarta: LKiS, 2012), 84.

${ }^{2}$ Lydia Kieven, Following the Cap-Figure in Majapabit Temple Reliefs: A New Look the Religious Function of East Javanese Temples, 14th and 15th Centuries (Leiden: Brill, 2013), 107.

${ }^{3}$ Ibid., 131.
} 
Dalam teks Jawa kuno, air juga dikenal sebagai tirtha. ${ }^{4}$ Di Bali, istilah 'tirtha' sampai sekarang masih digunakan untuk menyebut air suci. Pemandian suci tirtha memiliki fungsi simbolis penyucian spiritual. Kolam tirtha semacam itu terdapat di candi yang dibangun antara akhir abad ke-9 dan abad ke-15, seperti Songgoriti, Belahan, Jolotundo, Tikus, Panataran, dan Sukuh. Di Jawa Timur, pemandian suci terletak di kaki gunung atau lereng gunung, atau terhubung dengan candi atau pertapaan. Dengan melakukan ritual memasuki atau menggunakan air, pemuja menyucikan diri sebelum mendaki gunung dan mengunjungi tempat suci di gunung, atau memasuki lingkungan suci candi. ${ }^{5}$

Pada dasarnya ruang spiritual yang sering ditemukan untuk mengaktualisasikan keyakinannya terbagi menjadi beberapa bentuk, yaitu (1), petilasan, (2) makam, (3) gunung, dan (4) air. Berbagai kawasan ruang spiritual ini kadang-kadang tidak berdiri sendiri. Artinya, ada ruang air yang digabung dengan gunung, makam digabung dengan air, dan seterusnya. ${ }^{6}$

Candi Jolotundo adalah salah satu candi yang berdiri tepat di dekat sumber mata air dan terdapat sebuah kolam untuk menampung mata air tersebut. Simbolisme air yang lekat dengan penyucian spiritual kian memancarkan kesakralan air dalam mitos-mitos masyarakat Jawa pada saat itu, sehingga candi tersebut tidak pernah sepi pengunjung dan menjadi tempat ritual sesuci diri bagi sebagian orang dan kelompok.

Prosesi tradisi sesuci diri tersebut dilakukan dengan cara yang berbeda-beda oleh setiap orang maupun kelompok, sehingga memunculkan sebuah tanda tanya kenapa ada perbedaan ritual dalam tradisi tersebut. Peneliti mencoba mengetahui bagaimana relasi manusia dengan alam dalam fenomena tersebut, sehingga diketahui bagaimana instrumen alam memainkan peran penting dalam mencapai pengalaman spiritual terutama dalam tradisi sesuci diri.

\section{Sejarah Tradisi Sesuci Diri}

Sejarah tradisi sesuci diri yang dilakukan oleh banyak orang yang datang ke Candi Jolotundo terutama yang dilakukan oleh warga Desa

\footnotetext{
4 Tempat air suci juga disebut 'petirtaan' dalam bahasa Indonesia, atau 'patirthan' dalam bahasa Bali.

${ }^{5}$ Kieven, Following the Cap-Figure in Majapabit Temple Reliefs, 119.

' Suwardi Endraswara, Agama Jawa: Ajaran, Amalan, dan Asal-usul Kejawen (Jakarta: Narasi, 2017), 79.
} 
Seloliman sudah dilakukan secara turun temurun. Meskipun telah dilakukan secara turun temurun, belum diketahui sejak kapan tradisi ini bermula, namun menurut penuturan Mulyadi $^{7}$ tradisi sesuci sebenarnya berawal dari kepercayaan Hindu kemudian tradisi itu tidak hanya dilakukan oleh umat $\mathrm{Hindu}^{8}$ namun juga dilakukan oleh orang banyak termasuk umat Islam yang berada di Desa Seloliman. Jika mengacu pada kajian arkeologi yang dilakukan oleh Lydia Kieven pada candi-candi di Jawa Timur, terutama di Candi Jolotundo memang ada kedekatan hubungan antara tradisi sesuci dengan mitos penciptaan Gunung Penanggungan dan Candi Jolotundo.

Penciptaan amerta dituturkan dalam Samudramanthana, kisah 'pengadukan laut', dalam kaitan dengan gunung mistis Mahameru (Gunung Meru), singgasana para dewa. Ada dua versi kisah ini yang dikenal. Dalam versi Jawa Kuno, Adiparwa, bagian pertama dari Mababharata berbasis India, amerta muncul dari samudra susu setelah lautan diaduk menggunakan Mahameru sebagai pengaduk, sementara gunung ini ditopang oleh kura-kura. Dalam Tantu Panggelaran Jawa yang jauh lebih muda, kisah menuturkan pengangkutan Gunung Mahameru dari India ke Jawa oleh para dewa, amerta dikatakan muncul dari dunung tersebut ketika berlangsung pengadukan samudra. Dengan demikian, perubahan dari mitos berbasis India menjadi mitos Jawa di kemudian hari ada pergeseran dari laut ke gunung sebagai sumber air suci. ${ }^{9}$ Tirtha, seperti candi Jolotundo, di lereng gunung yang lebih rendah berfungsi untuk ritual memurnikan para peziarah dan, dengan demikian, untuk mempersiapkan mereka menuju ke tingkat pengetahuan esoterik yang lebih tinggi sebelum mendaki gunung. Dengan cara yang sangat praktis, air diperlukan untuk persediaan para pertapa dan peziarah dengan air minum; selama musim hujan, air disediakan oleh anak sungai dan sumber air. ${ }^{10}$

Dalam teks Jawa kuno, air juga dikenal sebagai tirtha. Di Bali, istilah tirtha sampai sekarang masih digunakan untuk menyebut air suci. Air tirtha sebagai arungan dan turunan ke dalam air bersinggungan dengan kualitas air sebagai wujud yang menyucikan. Ketika memasuki atau melintasi air, rohaniawan taraf lanjut disucikan dan melangkah ke tingkat spiritual yang lebih tinggi. Konotasi ini juga

${ }^{7}$ Mulyadi adalah salah satu warga Desa Seloliman dan menjadi pemangku adat di Desa Seloliman.

${ }^{8}$ Mulyadi, Wawancara, Candi Jolotundo, 14 November 2017.

${ }^{9}$ Kieven, Following the Cap-Figure, 114.

${ }^{10}$ Ibid., 300. 
sangat dikenal dalam ajaran agama Buddha, yang mengatakan bahwa menyeberangi air adalah simbol pencapaian kebijaksanaan. ${ }^{11}$

Mitos tentang pengadukan laut tersebut begitu dianggap sakral, sehingga air yang keluar dari gunung dianggap sebagai air suci atau amerta. Gunung Penanggungan menurut kepercayaan orang Hindu pada waktu itu merupakan replika dari gunung suci Meru, ciri khas Gunung Meru adalah bentuknya di mana satu puncak dikelilingi empat bukit yang lebih rendah, dan pada tingkat yang lebih bawah dikelilingi oleh empat bukit lagi. ${ }^{12}$ Ciri-ciri ini mirip dengan topografi Gunung Penanggungan di mana gunung tersebut dikelilingi oleh bukit-bukit kecil disampingnya, sehingga sumber air yang terletak di sekitarnya dianggap sebagai air suci, terlebih sumber air tersebut dibangun sebuah candi sehingga tampaklah kesucian dari air dan gunung tersebut. Meskipun hal tersebut hanya sebuah mitos, namun salah satu fungsi penting mitos khususnya pada masyarakat Jawa adalah sebagai alat pendidik, pelipur lara, protes sosial, dan sebagai kontrol dalam beretika. ${ }^{13}$

\section{Hening sebagai Harmonisasi Manusia dengan Alam}

Hening selalu dilakukan oleh masyarakat Jawa sejak dulu, bahkan sebelum masuknya agama Hindu Buddha. Hal ini dilakukan oleh masyarakat Jawa untuk menyatukan dirinya yang dianggap sebagai mikrokosmos dengan Tuhannya beserta dengan alam semesta atau yang sering disebut dengan makrokosmos. Menurut penuturan Yoyok, sebelum agama Hindu-Buddha masuk ke Jawa, masyarakat Jawa telah menganut agama atau keyakinan animisme dinamisme yang seolaholah menyembah pohon, batu dan benda-benda lainnya atau objek yang dikeramatkan sebagai titik fokus untuk sesajennya.

Sebenarnya masyarakat dulu tidak menyembah benda-benda tersebut, tetapi benda-benda tersebut sebagai perantara dan titik fokus untuk menyembah Sang Hyang yang mereka anggap sebagai Tuhan mereka. Sebelum Hindu-Buddha masuk, masyarakat Jawa telah mengetahui bahwa alam telah diciptakan oleh Sang Hyang, namun masyarakat Jawa tidak mengenal konsep ketuhanan. ${ }^{14}$ Spirit kepercayaan terhadap kekuatan dibalik segala fenomena alam yang

\footnotetext{
11 Ibid., 119.

12 Ibid., 115.

13 James Danandjaja, Folklor Indonesia: Imu Gosip, Dongeng, dan Lain-lain (Jakarta: Pustaka Utama Grafiti), 4.

14 Yoyok, Wawancara, Tunjung Sari, 24 Juli 2017.
} 
terjadi di sekitarnya pada akhirnya menemukan sebuah bentuk nyata setelah masuknya Hindu Buddha ke Jawa.

Keselarasan atau harmonisasi manusia dengan alam dalam bening juga dapat menerapkan sifat-sifat air. Adapun beberapa makna filosofis yang terdapat pada air yaitu:

1. Air yang selalu mengalir dari tempat yang tinggi ke tempat yang lebih rendah adalah supaya manusia mempunyai sifat rendah hati dan jauh dari sifat sombong, karena secara alami air tidak dapat mengalir dari tempat rendah ke tempat yang tinggi.

2. Air menempati ruang yang kosong adalah sebaik-baiknya manusia ialah manusia yang mengisi kekosongan hati orang lain. Dengan meniru sifat air yang mampu menjadi penolong makhluk hidup yang ada di dunia yang berada dalam masalah dan kekurangan, jadilah orang seperti itu menjadi manusia yang berbudi luhur dengan jalan menolong seseorang.

3. Air selalu mengalir ke muara adalah suatu misi tekad hidup. Ketika air menuju muara sangatlah berat penuh lika liku perjalanan, jadi membutuhkan sikap konsisten, tekun, dan sabar dalam menjalani hambatan dan ujian sampai menuju muara atau impian yang diinginkan.

Dengan menerapkan nilai-nilai filosofis air dalam ritual sesuci diri, maka akan diperoleh ketenangan batin. Selain itu ada beberapa doa yang ditujukan pada Tuhan untuk memperoleh rida-Nya, para leluhur dan alam semesta agar selalu selaras. Karena dalam tradisi sesuci diri yang dilakukan, sesuci memadukan unsur alam yaitu air, dengan tujuan adanya keselarasan antara manusia dan alam. ${ }^{15}$ Abstraksi dari sifat-sifat air yang telah dituturkan pada sesama kelompok maupun orang di luar kelompok yang meyakininya berguna untuk menjaga keselarasan tindakan manusia dengan sesamanya maupun dengan lingkungannya, sehingga tercipta sebuah keteraturan hidup dan bersosial.

Laku semedi dan hening yang dilakukan dengan mengadopsi nilainilai filosofis air merupakan salah satu cara untuk mengembalikan pemahaman bahwa manusia harus selalu melakukan budi lubur. Namun laku tersebut bukan hanya mencoba mengembalikan dan mengingatkan manusia untuk bersikap budi lubur tetapi mencoba kembali mengingatkan bahwa kejadian penciptaan manusia terdiri atas empat unsur pokok, yaitu tanah, api, angin, dan air. Dalam ajaran

15 Teguh, Wawancara, Trawas, 13 September 2017. 
tasawuf, ajaran bahwa manusia terdiri dari empat unsur; tanah, air, api, udara dan air. Diutarakan oleh 'Abd al-Karīm al-Jīlī bahwa keagungan adalah api, ilmu adalah air, kekuatan adalah udara, dan kebijaksanaan adalah tanah. Unsur-unsur yang merupakan penyusun unsur manusia paling halus. ${ }^{16}$

Kesatuan manusia dengan Tuhan atau Manunggaling Kawula Gusti juga coba dielaborasi dalam proses hening sebelum melakukan ritual sesuci diri, meskipun elaborasi tersebut tidak terlalu dominan. Tenangnya batin dan fokusnya batin pada Tuhan dalam proses hening menandakan telah dicapai sebuah harmonisasi antara Tuhan dan manusia. ${ }^{17}$ Manunggaling Kawula Gusti merupakan perwujudan sikap manembah. Manembah adalah menghubungkan diri secara sadar, mendekat, menyatu, dan manunggal dengan Tuhan. Manusia merupakan tajalli Tuhan melalui tujuh martabat yang menurun (tanäzul). Manusia pada hakikatnya sangat dekat atau bahkan samiji (manunggal) dengan Tuhan. ${ }^{18}$ Karena perbuatan manusia itu sendiri manusia yang awalnya sawiji (manunggal) dengan Tuhan tercipta sebuah kelir (batas) sehingga proses semedi dan hening diperlukan untuk mengembalikan sifat manunggal tersebut. Hening tidak hanya dapat dikaji dalam perspektif falsafah Jawa yang mencoba mencapai manunggal dengan pencipta, hening juga dapat dikaji dalam kajian fenomenologi eksistensialistik Heidegger, di mana hening merupakan proses Dasein memaknai eksistensinya.

\section{Hening sebagai Autentitas Dasein}

Hening adalah salah satu cara yang mudah dilakukan di mana saja untuk mengembalikan otentitas seseorang yang larut dalam keseharian. Namun ada beberapa tempat khusus yang memungkinkan proses hening dapat dilakukan secara maksimal.

Prosesi hening memaksa seseorang untuk introspeksi diri dan menghayati dunianya. Seseorang yang melakukan hal ini akan menyadari bahwa dia terlempar dalam dunia yang asing. Proses keterjatuhan subjek memang pelik. Ia didesak memahami dunia yang sedari awal dirasakan asing. Konsep keterlemparan Heidegger mengingatkan adanya relasi primordial subjek dengan alam. Alam

16 Simuh, Mistike Islam Kejawen Raden Ngabehi Ranggawarsita: Suatu Studi terhadap Serat Wirid Hidayat Jati (Jakarta: UI-Press, 1988), 313.

17 Endraswara, Mistik Kejawen: Inkretisme, Simbolisme, dan Sufisme dalam Budaya Spiritual Jawa (Yogyakarta: Narasi 2017), 45.

${ }^{18}$ Ibid., 46 
menyeruak menjadi fenomena asing, menakutkan dan mengancam subjek. Di balik rasa cemas itu muncul otensitas untuk mengatasi rasa takut terhadap alam yang berbeda, liar dan peduli terhadap alam sebagai bagian dari dunia Dasein. Konsekuensi pemikiran ini adalah bahwa seseorang yang menolak untuk menyadari posisinya dan menyangkal pentingnya dunia dikatakan Heidegger sebagai ketidakautentikan. ${ }^{19}$ Selain konsep hening, konsep asketisme juga merupakan salah satu dari cara Dasein mengembalikan keautentikan dirinya.

Pemahaman tentang asketisme telah ada sejak zaman masyarakat Jawa belum mengenal agama Hindu-Buddha, meningkatnya pembangunan candi di lereng Gunung Penanggungan pada masa akhir pemerintahan Majapahit juga mencerminkan banyaknya pemahaman tentang asketisme, pembangunan candi tersebut sebagai tanda bahwa semakin tinggi gunung maka semakin dekat dengan tempat para dewa. ${ }^{20}$ Selain itu pemahaman tentang perjalan hidup tak lepas dari kepercayaan hukum karma. ${ }^{21}$

Pemahaman terhadap karma memaksa seseorang untuk terus mempertanyakan tindakan bahkan keberadaannya sendiri di dunia. Bagi Heidegger, manusia di hadapan dunia telah selalu menafsirkan dunianya sebagai sesuatu, dan inilah cara manusia berada paling mendasar. Dengan menafsirkan dia menegaskan diri, dunia dan cara beradanya yang tertentu. Sebab, manusia telah selalu berada-di-dalamdunia (Being-in-the-world) yang tertentu, ${ }^{22}$ dan hanya manusia juga yang dapat menamai, memaknai, dan menafsirkan dunia sebagai dunia. Internalisasi nilai-nilai filosofis air dalam konteks sesuci adalah cara Dasein menangkap sebuah fenomena, dan dengan internalisasi tersebut menandakan adanya relasi pelaku spiritual dengan dunianya.

Pengadopsian nilai-nilai filosofis air yang dielaborasi dalam kehidupan Teguh menjadikan dirinya selalu mawas diri. Hal ini terjadi lantaran terdapat kekaguman Teguh terhadap nilai filosofis air. Dalam pengertian ini, dunia diartikan secara ontis yang artinya dunia dipahami sebagai totalitas objek-objek deskriptif. Dunia yang seolah-

19 Saras Dewi, Ekofenomenologi: Mengurai Disekuilibrium Relasi Manusia dengan Alam (Tangerang Selatan: Marjin Kiri, 2017), 105.

${ }^{20}$ Sanan, Wawancara, Candi Jolotundo, 20 September 2017.

${ }^{21}$ Mulyadi, Wawancara, Candi Jolotundo, 14 November 2017

22 Ito Prajna Nugroho, Fenomenologi Politik: Membongkar Politik Menyelami Manusia (Purworejo: Sanggar Pembebasan Pancasila, 2013), 16. 
olah lepas dari dirinya sebagai sang pemandang. ${ }^{23}$ Keseharian yang dialami seseorang atau Dasein tidak memungkinkan dirinya untuk menerima fenomena dan memiliki kekaguman terhadapnya, sehingga Dasein atau seseorang tidak autentik dan cenderung tidak lagi memaknai dunianya.

Proses hening yang dilakukan di Candi Jolotundo memberikan kesan mendalam bagi siapapun yang melakukannya, karena dengan melakukan hening di Jolotundo pelaku spiritual merasakan langsung secara empirik relasinya dengan dunia dan alam di sekitarnya. Kemampuan memahami Jolotundo sebagai pusat laku spiritual memberikan pemahaman terhadap pelaku spiritual akan kepentingannya dalam dunia ini.

Keterlibatan terhadap ruang spiritual sebagai bentuk keterlibatannya pelaku spiritual (Dasein) bersama dunianya. Dengan memberikannya pilihan, memungkinkan pelaku spiritual (Dasein) membangun sesuatu yang bermakna. Totalitas hubungan pelaku spiritual (Dasein) dengan Jolotundo tidak dapat dipisahkan. Totalitas itu memberi keistimewaan pada tempat-tempat yang dianggap memberikan ketenangan batin dan pengalaman spiritual, sehingga hubungan antara pelaku spiritual (Dasein) dengan ruang spiritualnya tidak dapat dipisahkan. Pelaku spiritual (Dasein) mempu mengerti tentang dirinya melalui perenungan terhadap relasi ontologisnya dengan dunia melalui ketersediannya instrumen yang telah dimaknai

Makna sesuci diri sebagai sarana membersihkan jiwa dan raga yang dipercayai oleh setiap orang yang datang ke Jolotundo menandakan bahwa adanya "transfer pemahaman". "Transfer pemahaman" terjadi karena adanya pemahaman universal terhadap tradisi sesuci diri, jikapun ada sebuah perubahan makna atau pergeseran makna terhadap tradisi tersebut dikarenakan lingkungan dan latar belakang pelaku yang berbeda. Keberbedaan latar belakang yang berbeda memungkinkan "percampuran pemahaman" dalam memandang tradisi sesuci diri dan Candi Jolotundo sebagai ruang spiritual. Selain itu dalam prosesi hening menggambarkan proses bagaimana pelaku spiritual mencoba memahami eksistensinya di dunia, refleksi diri dan memaknai hidupnya di dunia.

Ajaran atau konsep untuk mengenal diri sendiri telah ditekankan oleh Islam, adapun pokok ajaran Islam yaitu: kenalilah dirimu agar kamu mengenal Tuhanmu. Janganlah engkau tidak lupa akan dirimu.

${ }^{23}$ Donny Gahral Adian, Martin Heidegger (Jakarta: Teraju, 2003), 28. 
Ayat al-Qur'ān menerangkan: "Dan janganlah kamu seperti orangorang yang lupa akan Allah, lalu Allah menjadikan mereka lupa akan diri mereka sendiri. Mereka itulah orang-orang yang fasik." ${ }^{24} \mathrm{Hal}$ ini diperkuat oleh sabda Nabi Muhammad. "Barangsiapa mengenal dirinya, maka dia mengenal Tuhannya". "Alī b. Abī TTālib juga mengatakan, "Pengetahuan yang paling bermanfaat adalah pengetahuan tantang diri." Selanjutnya Mahatma Gandhi mengatakan:

Hanya ada satu kebenaran di dunia ini, dan kebenaran itu adalah mengenal diri senidri. Barang siapa mengenal dirinya, maka dia mengenal Tuhan dan lainnya. Barang siapa tidak mengenal dirinya, maka dia tidak mengetahui apapun. Di dunia ini ada satu kekuatan, satu kemerdekaan, dan satu keadilan, kekuatan itu adalah kekuatan penguasaan diri. Di dunia hanya ada satu kebajikan yaitu kebajikan menyayangi orang lain seperti menyayangi diri sendiri. Dengan kata lain, orang lain mesti dilihat sebagaimana kita melihat diri sendiri. Seluruh persoalan lainnya imajiner dan tidak ada. ${ }^{25}$

Hal ini menandakan bahwa proses hening yang dilakukan warga Desa Seloliman di Jolotundo bukanlah sebuah kegiatan musyrik, karena dengan prosesi hening tersebut selain refleksi diri, dan mendekatkan diri ke Tuhan tetapi juga sebagai bentuk pengenalan diri. orang-orang bebas melakukan refleksi diri dan meditasi sebagai sarana mengetahui jati diri dan eksistensi di manapun mereka mau. Bahkan dalam yoga, terdapat pula meditasi singkat guna menenangkan pikiran sehingga ada ketenangan dalam psikis seseorang yang melakukannya. Inilah mengapa Fenomenologi Eksistensialistik milik Heidegger dapat diterima oleh para agamawan. Fenomenologi ala Heidegger ini membiarkan Ada sebagai fenomen, sedangkan Heidegger sendiri tidak menerangkan secara jelas Ada itu seperti apa. Sehingga banyak kalangan agamawan menafsirkan Ada sebagai Tuhan.Bukankah Fenomenologi Eksistensialistik Heidegger mengandaikan kebermaknaan hidup pada subjek? Sedangkan mayoritas agama terutama Islam juga menginginkan kebermaknaan hidup bagi para umatnya dengan cara mengenal diri sendiri? Hal ini yang tidak dilihat oleh orang lain, sehingga orang lain hanya memandang aspek eksoteris setiap tradisi maupun agama yang berbeda, padahal tiap tradisi dan agama mempunyai titik temu pada aspek esoteris. Maka dari itu diperlukan pengetahuan esoteris,

\footnotetext{
24 al-Qur'ān, 59: 19.

25 Murtadha Muntahari, Falsafah Agama dan Kemanusiaan: Perspektif al-Qur'an dan Rasionalisme Islam (Yogyakarta: Rausyan Fikr, 2013), 19.
} 
sehingga tidak muncul sekat-sekat yang menimbulkan kesalahpahaman antaragama, satu kepercayaan dengan kepercayaan lain atau satu tradisi dengan tradisi lain.

\section{Sesuci Diri sebagai Revitalisasi Nilai Spiritual}

Tradisi sesuci sering dilakukan oleh mayoritas orang yang melakukannya sering dimaknai dengan membersihkan Jiwa dan raga. Namun jika dianalisis lebih jauh, makna sesuci bukan hanya tentang membersihkan Jiwa dan raga tetapi dalam tradisi sesuci juga terdapat kerinduan pelaku spiritual untuk kembali dekat bahkan manunggal dengan sang pencipta, bahkan dalam tradisi tersebut juga dapat dikatakan bahwa relasi tradisi sesuci yang dilakukan di Jolotundo sebagai salah satu cara pelaku spiritual untuk memahami eksistensinya dalam dunia.

Banyak orang menilai bahwa tradisi yang selalu dilakukan oleh para generasi sebelumnya adalah sebuah bentuk yang tidak dapat terus dilakukan pada zaman modern. Hal tersebut terjadi lantaran tuntutan masyarakat modern yang lebih dituntut untuk berpikir secara positivistik, realistis dan rasional sehingga segala bentuk tradisi masa lampau tidak lagi sesuai dengan tuntutan zaman saat ini, tidak terkecuali tradisi sesuci diri yang terus mencoba bertahan dari gemerlap pemikiran modern. Kehampaan yang dirasakan masyarakat modern coba dijawab oleh filsafat perennial di mana ada sebuah kebenaran universal yang bersifat metafisis dalam setiap agama. Banyaknya masyarakat modern yang cenderung berpikir positivistik, realistis dan rasional tetap mempunyai kecenderungan kembali pada hal-hal metafisis untuk memenuhi kebutuhan spiritual.

Tradisi sesuci mencoba untuk mengembalikan nilai-nilai spiritual yang telah terkikis oleh pemikiran modern. Dalam gemerlap pemikiran dan dunia modern, ada satu kebutuhan yang mulai terlupakan oleh masyarakat modern, yakni kebutuhan spiritual. Meskipun masyarakat modern mempunyai segala materi untuk memenuhi kebutuhan materilnya namun jika tidak diimbangi dengan terpenuhinya kebutuhan spiritual maka hidup tidak mempunyai pegangan dan makna.

Dalam mengembalikan nilai-nilai spiritual tersebut, tradisi sesuci tidak pernah lepas dari hantaman asumsi negatif yang mengatakan bahwa tradisi sesuci merupakan kegiatan yang berbau klenik dan musyrik. Asumsi seperti itu gegabah untuk diucapkan, jika tradisi 
sesuci ditinjau dalam ekoteologi, tradisi sesuci merupakan salah satu upaya untuk menyelamatkan alam yang mulai kehilangan tempatnya yang sederajat dengan manusia. Tradisi sesuci memandang bahwa alam merupakan teofani, yakni anggapan bahwa Tuhan merefleksikan diri-Nya dalam segala ciptaan-Nya.

Keresahan yang dialami oleh Mulyadi terhadap rusaknya alam di sekitar tempat tinggalnya menurutnya dikarenakan manusia tidak lagi bisa memandang bahwa alam juga merupakan ciptaan Tuhan, sehingga manusia mulai berbuat sesuka hatinya. Meskipun dalam tradisi sesuci sering dianggap orang secara umum sebagai sebuah kemusyrikan dan hal yang berbau klenik, namun menurut Mulyadi tradisi sesuci merupakan salah satu cara bagaimana para pelaku spiritual tetap memandang alam sebagai sebuah anugerah dari Tuhan dan harus tetap dijaga. ${ }^{26}$

Sejarah sesuci yang mempunyai akulturasi budaya dalam setiap metode dan maknanya ${ }^{27}$ menandakan bahwa setiap agama yang terakulturasi dalam tradisi sesuci mempunyai kebenaran universal tentang eksistensi alam. Tradisi seperti agama adalah kebenaran dan kehadiran. Ia memperhatikan subjek yang mengetahui objek yang diketahui. Ia datang dari sumber, dari segala sesuatu bermula dan pada sesuatu kembali. Tradisi tidak dapat dipisahkan berkenaan dengan wahyu dan agama, kesucian, gagasan ortodoksi, otoritas, kontinuitas dan reguleritas transmisi kebenaran. Begitu juga kehidupan spiritual, sains dan seni. Warna dan nuansa maknanya menjadi lebih jelas sekali hubungannya dengan tiap hal tersebut dan konsep pertinen lain serta kategori-kategori yang dijelaskan. ${ }^{28}$

Menurut Mulyadi, banyaknya orang yang meminta panduannya untuk diantarkan ke Jolotundo untuk melakukan sesuci diri didominasi oleh orang-orang yang memiliki beban hidup berlebih. Meskipun orang-orang tersebut memiliki kecukupan materi untuk memenuhi kebutuhannya, namun ada permasalahan spiritual yang tidak bisa dipenuhi oleh kebutuhan meterial, sehingga tujuan melakukan tradisi sesuci tersebut digunakan sebagai media untuk mengembalikan nilai-nilai spiritual yang telah hilang sekaligus menenangkan jiwa. Meskipun mayoritas orang yang meminta

\footnotetext{
${ }^{26}$ Mulyadi, Wawancara, Candi Jolotundo, 14 November 2017.

${ }^{27}$ Salam, Wawancara, Balai Desa Seloliman, 13 November 2017.

28 Seyyed Hossein Nasr, Knowledge and Sacred (New York: State University of New York Press, 1989), 64.
} 
bantuannya dalam melakukan sesuci tidak didasari untuk melestarikan tradisi leluhur, Mulyadi tetap merasa bahwa sesuci dapat menjadi salah satu cara membantu seseorang memperoleh pengalaman spiritual.

Saat penulis bertanya kepada Mulyadi siapa saja yang sering datang ke beliau, Mulyadi menjawab: banyak yang datang ke saya supaya minta dipandu melakukan ritual di Jolotundo. Bukan berarti saya paranormal, tapi memang saya dipercaya oleh orang-orang untuk memandu mereka karena itu sudah tugas sebagai pemangku adat. Kebanyakan orang yang datang ke saya adalah orang-orang yang menjabat sebagai pegawai pemerintah (PNS) dan orang yang punya masalah keluarga. Namanya juga manusia, pasti punya masalah. Kebanyakan dari mereka adalah orang-orang yang punya kecukupan materi, tetapi ya kalau ada masalah batin tidak bisa diobatin dengan uang atau mobil, caranya ya harus memperbanyak pendekatan ke Tuhan. ${ }^{29}$

Contoh kasus tersebut menandakan bahwa tradisi sesuci merupakan cara penyegaran kembali (refreshing) yang dilakukan masyarakat modern di tengah terpaan gerus positivisme yang malah berbalik menjadi sebuah mitos baru dalam kehidupan manusia. Hal ini telah dijelaskan oleh Frithjof Schuon yang dinukil oleh Abdul Kadir Riyadi dalam bukunya Antropologi Tasawuf bahwa manusia terbagi atas dua hal asasi, yang pertama, sisi kognitif dan yang kedua adalah sisi afektif. $^{30}$ Ketika kaum postivis dengan dalih ilmiahnya lebih mendahulukan sisi kognitif belaka, hal ini sama saja dengan mencederai makna manusia, karena manusia modern dinilai telah pincang secara makna paling asasi yaitu manusia minus sisi afektif. Ketika manusia telah pincang secara maknawi, sejatinya dengan kata lain manusia tak lagi memiliki sebuah keseimbangan. pemaknaan dalam dirinya, dan berdampak pada kegagapan manusia dalam mengecap maupun memaknai fenomena-fenomena sosial dan sebagainya.

Tradisi sesuci dipandang perlu dalam mengembalikan dahagadahaga sprititual seperti yang telah dijelaskan Sayeed Hossein Nasr sebagai ciri esensial masyarakat modern. Pasalnya tradisi sesuci dapat mengembalikan kepincangan makna dalam asasi manusia kembali seimbang dengan sisi afektif manusia. Bentuk kemerdekaan

\footnotetext{
${ }^{29}$ Mulyadi, Wawancara, Candi Jolotundo, 14 November 2017.

30 Abdul Kadir Riyadi, Antropologi Tasawnf: Wacana Manusia Spiritual dan Pengetahuan (Jakarta: LP3ES, 2014), 209.
} 
pemaknaan manusia antara lain adalah mengembalikan manusia pada kesadaraan spiritual dan juga manusia sebagai bagian dari the other.

Hal ini dapat menjadi sebuah jawaban terhadap tuduhan kerusakan alam oleh kebanyakan pemikir barat yang dilakukan oleh kaum scientist. Dalam konsep muksa dalam pandangan Mulyadi ketika melakukan sesuci ada kekaguman terhadap ciptaan Tuhan melalui alam. Adanya eksploitasi dan kerusakan alam terjadi karena kita lupa bahwa alam juga merupakan ciptaan Tuhan dan alam juga merupakan perwujudan dari Tuhan. Ketika terjadi harmonisasi dengan alam, kita akan sadar bahwa setiap langkah yang kita pijak di bumi sama halnya kita berjalan di atas ibu pertiwi. Kesadaran seperti itu akan meminimalisir ego manusia. ${ }^{31}$

Perlunya peningkatan kebutuhan spiritual tidak selalu harus dilakukan dengan cara ziarah ke makam para wali, peralihan cara memenuhi kebutuhan spiritual dari ziarah makam wali ke cara mendaki gunung dan melakukan doa bersama di sekitar lereng gunung merupakan alternatif dalam mengembalikan nilai spiritual. Hal ini dilakukan karena mulai maraknya bisnis-bisnis wisata spiritual ke tempat-tempat tertentu terutama makam-makam para tokoh besar Islam, sehingga menjadikan tempat-tempat tersebut ramai pengunjung, dan tidak lagi menjadi tempat yang tepat untuk melakukan refleksi diri. Gunung dan alam terbuka menjadikan seseorang lebih menghayati dirinya dalam melakukan refleksi kehidupan.

Dulu sewaktu masih aktif dan sering ziarah ke makam para wali saya masih merasa nyaman berdoan di sana. Namun setelah banyaknya bisnis ziarah ke makam para wali atau tokoh besar Islam, tempat-tempat seperti makam para wali menjadi ramai sehingga tidak bisa lagi konsentrasi berdoa. Setiap hendak berdoa dengan tenang, orang-orang di samping saya berdoa sambil berteriak-teriak, ada pula yang sampai sesak-sesakkan saat duduk. Maka dari itu saya beralih dari ziarah wali menuju alam terbuka seperti gunung, karena di gunung tempatnya sepi, kita juga bisa langsung melihat kebesaran ciptaan Allah. ${ }^{32}$

Kedekatan dengan alam tidak hanya mengembalikan nilai-nilai spiritual namun juga mencoba mengembalikan rasa takjub (sense of wonder) terhadap alam sebagai pengejewantahan Ilahi. Masyarakat modern saat ini telah kehilangan rasa itu sehingga dijumpai banyak

\footnotetext{
${ }^{31}$ Mulyadi, Wawancara, Candi Jolotundo, 14 November 2017.

32 Sanan, Wawancara, Candi Jolotundo, 5 September 2017.
} 
eksploitasi terhadap alam secara massif. Selain itu dengan dekatnya manusia dengan alam, manusia belajar untuk memahami eksistensinya di dunia dengan cara refleksi atas apa yang telah diperbuat.

Sejalan dengan Hossein Nasr, Toshihiko Izutsu juga memandang bahwa alam mempunyai peran besar tidak hanya dalam perjalanan hidup manusia, tetapi alam juga merupakan 'tanda' (āyah) untuk memahami Tuhan. Menurutnya ada dua tipe pemahaman timbal balik antara Tuhan dan manusia. Yang pertama bersifat linguistik atau verbal, yakni melalui penggunaan bahasa yang dipahami oleh kedua belah pihak, sedangkan yang lainnya bersifat non-verbal, ${ }^{33}$ dan alam termasuk dalam pola komunikasi non-verbal. Mitos tentang proses pengadukan laut menggunakan gunung Meru oleh para dewa, sehingga anggapan gunung sebagai tempat suci dan segala yang berada di sekitarnya harus tetap dijaga nilai kesakralannya menandakan bahwa ada pola komunikasi non-verbal dengan Tuhan tetap dijaga. Tradisi sesuci yang merupakan bagian dari mitos tersebut kesakralannya tetap dijaga, sistem ide dalam tradisi tersebut mulai dari dulu sampai sekarang tetap dijaga menjadikan tradisi ini tetap eksis sampai sekarang meskipun ada sedikit perbedaan ritual dalam pelaksanaannya.

\section{Sesuci Diri dalam Tinjauan Ekoteologi}

Tradisi sesuci sering dilakukan oleh orang-orang dengan mendasarkan pada perhitungan Jawa (petungan). Hal ini dilakukan karena menurut kepercayaan mayoritas masyarakat Jawa petungan merupakan cara untuk menghindari celaka. Seperti yang diungkapkan oleh Salam, bahwa sesuci sering dilakukan mulai malam 1 Selo sampai malam 29 Selo. Biasanya mereka berpatokan pada dua hal: 1. Berpatok pada malam weton, (hari kelahiran menurut kepercayaan masingmasing). 2. Hari baik, hari baik menurut kepercayaan masing-masing, ada yang mengatakan hari baik itu malam Jumat Legi, malam Jumat Kliwon, malam Selasa Kliwon, malam 14 Jawa, malam 15 Jawa. ${ }^{34} \mathrm{Hal}$ serupa juga dilakukan oleh Sanan yang sering melakukan sesuci di Jolotundo pada tanggal 15 Jawa atau malam purnama. ${ }^{35}$

Banyak orang Jawa melakukan kegiatan slametan atau kegiatan lain termasuk laku spiritual didasarkan pada sistem numerologi Jawa.

33 Toshihiko Izutsu, God and Man in The Qur'an: Semantics of the Qur'anic Weltanschaunng (Kuala Lumpur: Islamic Book Trust, 2004), 142.

${ }^{34}$ Salam, Wawancara, Balai Desa Seloliman, 13 November 2017.

${ }^{35}$ Sanan, Wawancara, Candi Jolotundo, 5 September 2017 
Dasar sistem petungan ini terletak konsep metafisik Jawa yang fundamental: cocog. Cocog berarti sesuai, sebagaimana kesesuaian kunci dengan gembok, obat mujarab dengan penyakit, sebuah pemecahan dengan soal matematik serta persesuaian seorang pria dengan perempuan yang dinikahinya (kalau tidak, mereka bercerai). Dalam pengertian yang paling abstrak dan luas, dua hal yang terpisah akan cocog apabila perjumpaan mereka membentuk sebuah pola estetis. Geertz menyatakan secara tidak langsung sebuah pandangan kontrapuntal terhadap alam raya di mana yang penting adalah hubungan alamiah antara elemen-elemen yang terpisah-ruang, waktu dan motivasi manusia-bagaimana mereka itu diatur untuk menghasilkan paduan nada dan menghindari ketidaksesuaian. ${ }^{36}$ Melakukan petungan dalam setiap melakukan kegiatan yang dianggap penting oleh masyarakat Jawa bertujuan untuk tetap menjaga sebuah harmonisasi terhadap alam dan kecelakaan saat melakukan kegiatan.

Alam mempunyai peran penting dalam budaya Jawa, segala sistem budaya didasarkan atas refleksi terhadap alam sehingga alam berperan sebagai guru kehidupan dalam perkembangan budaya Jawa. Menurut Jacques Ellul yang dikutip oleh Gregory Wagenfuhr dalam jurnal Philosophy of Engineering and Technology, manusia hidup di lingkungan di mana semua yang dibutuhkan untuk hidup. Ellul mengatatakan untuk hidup dan bukan hanya bertahan hidup. Manusia mengaturnya dan manusia beradaptasi dengannya, tetapi manusia juga mencoba untuk menyesuaikan alam dengan manusia.

Dalam kaitannya dengan lingkungan, manusia memiliki kesempatan untuk menjalankan salah satu fungsi kehidupan yang paling mendasar, yaitu simbolisme. Lingkungan memberi manusia peluang untuk menciptakan simbol, dan inilah kekayaan yang memacu manusia untuk berkembang. Semua faktor dalam kehidupan dimediasi melalui lingkungan. Dengan demikian, lingkungan adalah (1) kondisi kehidupan, (2) sumber kematian, dan (3) yang memediasi semua aspek kehidupan dan dengan demikian menyediakan konten untuk simbol. ${ }^{37}$ Pandangan hidup dan relasi masyarakat Jawa dengan alam memunculkan budaya-budaya yang merupakan refleksi dari dirinya dengan alam.

\footnotetext{
${ }^{36}$ Clifford Geertz, Agama Jawa: Abangan, Santri, Priyayi dalam Kebudayaan Jawa, terj. Aswab Mahasin dan Bur Rasuanto (Depok: Komunitas Bambu, 2014), 32.

37 Gregory Wagenfuhr, "Postmodernity, the Phenomenal Mistake: Myth and Environment," Philosophy of Engineering and Technology, Vol. 13 (2013), 231.
} 
Namun budaya seperti ini tak lepas dari cibiran orang-orang yang belum mengetahui esensi dari budaya Jawa, termasuk tradisi sesuci. Tradisi sesuci yang dilakukan di Jolotundo sering dianggap sebagai sebuah kegiatan musyrik, padahal tradisi tersebut hanya ingin menjaga tradisi nenek moyang yang mulai terpinggirkan zaman.

Saat peneliti bertanya pada salah satu informan yang tidak mau disebutkan identitasnya, bagaimana tanggapan anda tentang orang yang sering melakukan ritual di Jolotundo? Informan tersebut mengatakan, ya apapun yang dilakukan seseorang di Jolotundo, menurut saya itu musyrik. Hal itu dikarenakan Jolotundo itu bukan tempat meminta, kalau mau meminta sesuatu ya pada Allah, bukan pada leluhur, dahyang atau tempat keramat. Saya tidak mau menyebut nama seseorang atau kelompok yang sering datang ke situ, cuma dari pada buang-buang uang buat beli dupa, kemenyan dan sesaji mending uangnya tersebut disodakohkan ke orang yang membutuhkan, anak yatim atau ke masjid. Apa namanya bakar dupa dan kemenyan dengan meminta pada leluhur kalau bukan syirik. Kalau ke Jolotundo hanya sekadar untuk wisata sah-sah saja, masalahnya yang datang ke sana itu banyak yang sering meminta sesuatu. ${ }^{38}$

Salam tidak setuju dengan tuduhan seperti itu, karena dalam proses ngawerubi bukan berarti menyembah selain Tuhan, namun dalam proses itu juga kita mendoakan nenek moyang kita. Artinya, tidak ada konotasi syirik. Jadi ibaratnya dalam tradisi Islam Jawa ada acara tahlilan di mana dalam acara tersebut bertujuan untuk mendoakan keluarga yang telah meninggal. Dalam ritual sesuci terutama dalam proses ngaweruhi tidak berbeda dengan proses tahlilan atau slametan dalam budaya Islam Jawa. ${ }^{39}$

Senada dengan Salam, Mulyadi juga menyampaikan keberatannya terhadap tuduhan syirik, dia menuturkan memang banyak orang yang beranggapan bahwa setiap orang yang datang ke Jolotundo melakukan kegiatan syirik, namun hal itu tidaklah benar. Niatan untuk datang ke Jolotundo termasuk kegiatan sesuci adalah untuk mengagumi ciptaan Tuhan, dan segala permintaan yang terkandung dalam ritual sesuci tetap ditujkan pada Tuhan Yang Maha Esa melalui perantara (tawāsul) air suci di Jolotundo. Ibarat dalam budaya Islam masyarakat Indonesia adalah banyaknya kegiatan ziarah makam ke wali-wali yang dianggap berjasa dalam perkembangan Islam.

\footnotetext{
38 Anonim, Wawancara, Desa Srigading, 10 November 2017.

${ }^{39}$ Salam, Wawancara, Balai Desa Seloliman, 13 November 2017.
} 
Para warga datang ke Jolotundo hanya untuk mengagumi maha karya orang terdahulu atau para raja yang membangun Jolotundo, karena melalui para raja, dan raja adalah manusia pilihan Tuhan, Tuhan memberikan hidayah atau ketenteraman pada masyarakat zaman dahulu. Orang-orang yang beranggapan bahwa orang yang datang ke Jolotundo adalah sebuah kegiatan syirik menandakan orang yang berkata syirik tersebut mempunyai kedangkalan berpikir. Kesalehan sering ditandai dengan banyaknya simbol agama yang melekat pada dirinya, sebenarnya kesalehan bukan seperti itu, namun bagaimana orang tersebut bersikap terhadap orang lain. Sebenarnya jika mau menelisik dengan lebih detail, ziarah wali juga mempunyai potensi untuk musyrik, karena ada pula orang datang ziarah ke Walisongo bukan karena tawāsul namun dengan niatan untuk meminta. ${ }^{40}$

Pandangan banyak orang tentang tradisi sesuci yang dianggap syirik menandakan tidak adanya refleksi terhadap realitas dan kebenaran suatu tradisi. Menurut Gai Eaton ${ }^{41}$ yang mengutip buku antropolog Ruth Benedcit yang dinukil oleh Abdul Kadir Riyadi dalam bukunya Antropologi Tasawnf, "pada Mulanya Tuhan memberikan setiap orang sebuah cangkir, dan darinya mereka meminum air." Benedict lalu menggarisbawahi bahwa "cangkir itu kini telah pecah berkeping-keping." " It Itulah gambaran masyarakat saat ini, apa yang menjadi sandaran bagi manusia kini hancur total dan bahkan menjadi sumber bahaya. Itu berbeda jauh dengan masyarakat tradisional.

Masyarakat tradisional mempunyai cangkir utuh (sebut saja agama) yang merupakan pegangan hidup bagi mereka, hal tersebut yang tidak ada dalam kehidupan masyarakat modern yang hanya mempunyai serpihan-serpihan cangkir dan menjadikannya sebagai pegangan hidup. Serpihan-serpihan tersebut lantas dibandingkan dengan serpihan-serpihan yang dimiliki oleh orang atau golongan lain yang memiliki corak berbeda dengan serpihannya, sehingga saling menyalahkan atas perbedaan tersebut dan menganggap serpihannya

\footnotetext{
${ }^{40}$ Mulyadi, Wawancara, Candi Jolotundo, 14 November 2017.

${ }^{41}$ Nama lengkapnya adalah Charles le Gai Eaton. Pernah kerja di Jamaica dan Mesir sebagai wartawan, dan sebagai diplomat untuk pemerintah Inggris. Ia adalah penulis beberapa buku penting di antaranya Richest Vein yang membahas mengenai ajaran dan pikiran Rene Guenon, King of the Castle dan yang bersinggungan dengan Islam berjudul Islam and the Destiny of Man.

${ }^{42}$ Riyadi, Antropologi Tasawuf, 218.
} 
adalah yang paling benar (truth claim). Mereka tidak menyadari bahwa serpihan-serpihan yang memiliki corak berbeda tersebut berasal dari satu cangkir (katakan esensi agama).

Ketidakmampuan masyarakat modern dalam memandang sebuah tradisi ini mengakibatkan sebuah diskriminasi atas kelompok minoritas sehingga melahirkan sebuah tuduhan-tuduhan yang cenderung mendiskreditkan sebuah kelompok beserta segala atribut atau budayanya. Tradisi sesuci diri yang dilakukan di Jolotundo menurut Salam karena Jolotundo adalah patirthan (kolam air), sedangkan sesuci juga identik dengan air, maka lebih afdal atau diutamakan dilakukan di Jolotundo. Selain itu ritual sesuci dilaksanakan di Jolotundo sebagai sarana melanjutkan tradisi dari nenek moyang, karena Jolotundo sendiri adalah tempat para leluhur bertapa dan bersuci para raja. ${ }^{43}$

Pengalaman religius yang dialami setiap pelaku spiritual dalam melakukan sesuci di Jolotundo memang bersifat primordial. Menurut Mircea Eliade pengalaman religius merupakan refleksi terhadap dunia. Pemilihan atau pembuatan ruang spiritual didasarkan atas bahwa ruang tersebut merupakan titik tetap, poros pusat untuk semua orientasi masa depan. Ketika sakral memanifestasikan dirinya dalam hierofani apa pun, ada juga wahyu dari realitas absolut, yang menentang non-realitas dari bentangan luas di sekitarnya. ${ }^{44}$ Hal ini tampak dalam penuturan Salam bahwa secara simbolisasi Jolotundo juga sebagai tempat yang sakral. ${ }^{45}$ Ini dibuktikan dengan adanya replika Gunung Penanggungan dalam bentuk pahatan batu di atas Candi Jolotundo.

Jadi jelaslah bahwa sejauh mana penemuan-yaitu, wahyu dan pengalaman spiritual—dari ruang suci memiliki nilai eksistensial bagi manusia religius; karena tidak ada yang bisa dimulai, tidak ada yang bisa dilakukan, tanpa orientasi sebelumnya-dan orientasi apa pun berarti memperoleh titik tetap. Karena alasan inilah manusia religius selalu berusaha untuk memperbaiki tempat tinggalnya di "pusat dunia". ${ }^{46}$

\footnotetext{
${ }^{43}$ Salam, Wawancara, Balai Desa Seloliman, 13 November 2017.

${ }^{44}$ Mircea Eliade, The Sacred and the Profane: The Nature of Religion, translated from the French by Wlliard R. Trask (New York: Harcourt, Brace World, 1959), 20.

${ }^{45}$ Salam, Wawancara, Balai Desa Seloliman, 13 November 2017.

${ }^{46}$ Eliade, The Sacred and the Profane, 21.
} 
Pemahaman ontologis dalam akulturasi tradisi sesuci jelaslah terdapat suatu titik temu di dalamnya, yakni memandang alam sebagai "tanda" ayah Tuhan, Seyyed Hossein Nasr ingin mengembalikan pandangan bahwa alam adalah teofani atau pengejewantahan ilahi, Pemahaman ini yang telah hilang pada masyarakat modern yang lebih mementingkan kesalehan normatif dan melupakan nilai-nilai esensial dalam agama, terutama dalam hal menyangkut ekologi. Saat para pemeluk agama lebih mementingkan kesalehan normatif yang hanya mengacu pada hubungan vertikal antara Tuhan dan manusia, maka instrumen komunikasi Tuhan dan manusia berupa komunikasi nonverbal akan dilupakan. Tradisi sesuci ingin tetap mempertahankan nilai-nilai kesakralan alam dalam sebuah simbolisme, saat manusia telah melupakan kesakralan alam dalam masa modern saat ini.

Letak Desa Seloliman yang secara geografis terletak di daerah dataran tinggi dan dikelilingi oleh beberapa gunung memberikan sebuah pemahaman masyarakat bahwa alam merupakan segalanya dalam kehidupan mereka. Alam bukan hanya sebagai instrumen untuk hidup dan bertahan hidup, namun lebih jauh, alam telah menjadi sebuah 'lahan subur' dalam mengaktifkan imajinasi berupa mitosmitos yang terus terjaga sejak dulu sampai sekarang. Hal ini menandakan bahwa letak geografis sangat mempengaruhi pemikiran seseorang bahkan kelompok masyarakat.

Tradisi lokal terutama tradisi sesuci adalah langkah bagaimana sistem ide terutama mitos dimanifestasikan dalam sebuah ritual dan sifatnya lebih down to earth, sehingga mengaktifkan kembali mitos dan tradisi lokal yang erat dengan kosmos menjadi salah satu cara untuk menghindarkan lingkungan dari kerusakan yang ditimbulkan oleh manusia. Ekoteologi mencoba mengembalikan kesadaran spiritual bahwa alam adalah pengejewantahan Ilahi. Namun ekoteologi tidak bisa berdiri sendiri dalam menghadapi krisis lingkungan, ekoteologi harus ditopang oleh tradisi lokal yang berkaitan dengan alam atau kosmos untuk dapat menjadi sebuah solusi konkret. Hal ini disebabkan konsep tentang ekoteologi terutama dalam pandangan Hossein Nasr masih dalam konsep abstrak dan belum konkret dalam menghadapi eksploitasi alam secara masif, jika ekoteologi hanya sanggup mengembalikan kesadaran spiritual bahwa alam adalah pengejewantahan Ilahi, dan tradisi lokal sebagai langkah praksisnya, maka ekoteologi dan tradisi lokal harus saling berafiliasi satu sama lain guna menghindari eksploitasi alam secara masif. 
Dengan menerapkan hal tersebut, agama tidak lagi timpang dalam kehidupan manusia. Selama ini langkah praksis agama dalam kehidupan manusia hanya melahirkan teologi pembebasan dalam menghadapi persoalan kemanusiaan, sehingga seakan-akan fokus sebuah agama hanya memberi manfaat bagi kehidupan manusia, sedangkan persoalan ekologi cenderung diabaikan. Ide tentang air Jolotundo sebagai air suci para dewa dan ritual tradisi susuci diri adalah wujud dari afiliasi ekoteologi dan tradisi lokal, sehingga dari afiliasi tersebut agama dan teologi dapat menyentuh ranah ekologi secara praksis dan bukannya membuat langkah pasif ataupun menjaga jarak dengan kerusakan ekologi.

Hossein Nasr dalam bukunya Knowledge and Sacred menjelaskan bahwa tiap agama adalah pusat dan awal tradisi, yang memperpanjang prinsip-prinsip agama terhadap wilayah-wilayah yang berbeda. Kenyataannya, kata tradisi dihubungkan secara etimologis dengan transmisi dan berisi spektrum makna gagasan tentang pengetahuan, praktik, teknik, hukum, bentuk dan sejumlah elemen, baik bersifat oral maupun tertulis. Tradisi juga merupakan kebenaran yang melukiskan jiwa manusia, dan sehalus nafas atau bahkan pandangan sekilas mata, melalui mana ajaran-ajaran tertentu ditransmisikan. Dalam pengertiannya yang lebih universal, tradisi dapat dianggap memasukkan prinsip-prinsip yang mengikat manusia ke surga. Dalam hal ini tradisi mengimplikasikan kebenaran-kebenaran ciri supraindividual, yang berakar dalam sifat realitas.

Tradisi seperti agama, adalah kebenaran dan kehadiran. Ia datang darimana segala sesuatu berasal dan berakhir di mana segala sesuatu kembali. Tradisi tidak dapat dipisahkan berkenaan dengan wahyu dan agama, kesucian, gagasan ortodoksi, otoritas, kontinuitas dan reguleritas trnasmisi kebenaran, eksoterik dan esoterik, begitu juga kehidupan spiritual, sains dan seni. ${ }^{47}$ Dalam penjelasan ini Nasr mencoba menjelaskan bahwa tradisi tidak bisa dipisahkan dari makna perennial sebuah agama, dalam tradisi sesuci yang berakulturasi dari agama Hindu, Buddha dan Islam juga tidak dapat dipisahkan ketiga agama tersebut dalam memandang alam.

Tradisi sesuci merupakan intisari bagaimana cara menghormati, bersikap dan memandang alam dalam ritus sehari-hari. Namun setiap tradisi bahkan seperti tradisi sesuci diri tidak hanya sebagai refleksi makna agama terhadap alam, namun sebuah tradisi terutama tradisi

\footnotetext{
${ }^{47}$ Nasr, Knowledge and Sacred, 64.
} 
sesuci dapat menjadi modus individu maupun kelompok untuk menyadari dirinya di dalam dunianya. Tradisi sesuci diri bukanlah sebuah tradisi yang lahir begitu saja dari rahim sejarah dan mitos tentang penciptaan gunung Meru dan air suci (amerta), namun tradisi itu telah melalui segala proses dialektik dan modus eksistensial individu maupun kelompok, sehingga melahirkan sebuah kebermaknaan pada setiap pelaku spiritual yang melakukannya. Hal ini yang kurang diperhatikan oleh konsep tradisi yang dijelaskan oleh Nasr, makna-makna yang hadir pada tradisi terutama tradisi sesuci diri bukan semata karena sifat perennis agama dalam memandang alam, apabila hal itu yang terjadi maka tradisi hanya sebuah sistem pengetahuan dan ritual yang kering tanpa makna. Keberlangsungan makna dalam setiap tradisi terus dijaga oleh relasi subjek objek atau antara individu yang sadar akan dirinya dalam memandang sebuah tradisi, sehingga makna dalam sebuah tradisi terus terjaga.

Pentingnya pengetahuan terhadap pandangan agama dalam memandang alam dan makna tradisi harus tetap dijaga. Hal ini dilakukan supaya tidak ada lagi dikotomi pendapat dalam memandang sebuah tradisi. Tradisi adalah sebuah usaha manusia dalam memahami kenyataan secara rasional, termasuk usaha memahami fenomena alam dan kejadian alam semesta. Tradisi mengikat manusia pada Tuhan dan pada saat yang sama manusia juga sebagai anggota komunitas suci atau rakyat atau apa yang disebut sebagai ummah. Memahami dalam pengertian ini, agama dapat dianggap sebagai asal tradisi, seperti permulan surgawi, yang melalui wahyu memanifestasikan prinsipprinsip dan kebenaran tertentu, yang aplikasinya kemudian hari terdiri dari tradisi. ${ }^{48}$

Hukum-hukum syariat dalam Islam yang mengatur kehidupan umat Muslim jika ditelisik lebih jauh, adalah sebuah representasi atas hukum-hukum alam (kausalitas) yang diterapkan pada sebuah tatanan kehidupan tanpa menghilangkan unsur metafisika. Manusia diikat oleh dunianya bukan hanya karena sebab-sebab fisik, namun diikat juga oleh sebab-sebab metafisik. Melihat kosmos sebagai teofani tidaklah membebaskan hukum kausalitas yang meliputinya, tapi melihat kosmos sebagai bentuk, refleksi, sifat Ilahi dan ketegori-kategori ontologis terselubung yang akan menyembunyikan refleksi Ilahi. ${ }^{49}$

\footnotetext{
${ }^{48}$ Ibid., 67.

${ }^{49}$ Ibid., 184.
} 
Namun, melihat alam sebagai teofani tidaklah semudah mengatakan mengucapkan "alam adalah cerminan Tuhan", namun melihat alam sebagai teofani harus berdasarkan kesadaran individu. Dengan Fenomenologi Eksistensialistik Heidegger, subjek menjadi autentik ketika subjek menyadari Ada melalui relasinya dengan alam. Bekal autentitas subjek ini, akan membawa individu pada pemahaman bahwa alam dan segala sesuatu mempunyai tujuan (telos), jika subjek telah sampai pada titik ini, maka subjek dapat memandang alam sebagai teofani.

Melihat alam sebagai teofani perlu kembali pada kebenaran bahwa realitas bersifat hierarkis, dan kosmos tidak dilahirkan dari aspek fisik saja. Menurut Nasr, alam diciptakan secara hierarkis, dan penciptaan manusia mempunyai kemiripan dengan penciptaan alam, sehingga manusia dapat juga disebut sebagai mikro kosmos.

Nasr meminjam konsep Ibnu Arabi tentang lima kehadiran Tuhan (al-hadärah al-ilähìyah al-khamsah/five divine presence). Pertama, hähüt, yakni diri Tuhan yang dengan segala sifat kesempurnaan-Nya (esensi realitas). Kedua, lähüt, yaitu taraf tempat nama dan sifat-sifat Tuhan (quiditas). Ketiga, jabarūt, yakni taraf dunia malaikat tertinggi (spirit). Keempat, malakèt, yaitu taraf dunia jiwa dan materi halus (animistik). Kelima, mulk, yakni taraf dunia fisik-material. Taraf material tersebut juga sering disebut nāsüt. Dalam gradasi tingakatan itu, taraf yang lebih tinggi mesti mencakup yang lebih rendah. ${ }^{50}$

Penjelasan yang telah dijelaskan oleh Nasr menandakan bahwa segala realitas akan bermuara pada satu esensi, yakni esensi Tuhan. Maka dalam konteks tradisi sesuci diri, para pelaku spiritual memandang Gunung Penanggungan dan air suci yang keluar dari gunung tersebut berasal dari para dewa, dan kesadaran tersebut telah dibentuk oleh proses hening sebagai refleksi diri, dan menjadikan pemahaman ontologis terhadap alam terus dipelihara, sehingga menciptakan sebuah keteraturan relasi antara manusia, alam dan Tuhan.

\section{Penutup}

Relasi manusia dan alam dalam tradisi sesuci diri di Candi Jolotundo dapat ditinjau dari dua perspektif, yakni perspektif falsafah Jawa tentang konsep manusia dan Tuhan serta perspektif

\footnotetext{
${ }^{50}$ Ach. Maimun, Seyyed Hossein Nasr: Pergulatan Sains dan Spiritualitas Menuju Paradigma Kosmologi Alternatif (Yogyakarta: Ircisod, 2015), 128.
} 
fenomenologi eksistensialistik. Dalam perspektif falsafah Jawa, tradisi sesuci dilakukan guna mendekatkan diri terhadap Tuhan, terutama dalam prosesi hening. Proses hening merupakan tahap di mana seseorang mencapai harmoni dengan Tuhan dan alam, dalam prosesi hening tersebut juga menjadi sarana manunggal dengan Tuhan sehingga kedekatan dengan Tuhan menjadikan batin seseorang menjadi tenang, proses hening juga memungkinkan seseorang untuk refleksi diri, sehingga setiap perbuatan seseorang akan terkontrol.

Dalam perspektif fenomenologi eksistensialistik, proses bening yang dilakukan di Candi Jolotundo memberikan kesan mendalam bagi siapapun yang melakukannya, karena dengan melakukan bening di Jolotundo pelaku spiritual merasakan langsung secara empirik relasinya dengan dunia dan alam di sekitarnya. Kemampuan memahami Jolotundo sebagai pusat laku spiritual memberikan pemahaman terhadap pelaku spiritual akan kepentingannya dalam dunia ini. Dengan memberikannya pilihan, memungkinkan pelaku spiritual (Dasein) membangun sesuatu yang bermakna. Selain itu, dalam laku spiritual tersebut, memungkinkan seseorang memahami relasi ontologisnya dengan alam dan dunianya, sehingga membentuk rasa kepedulian seseorang dengan alam dan dunia yang dibangunnya.

Makna tradisi sesuci diri mencoba untuk mengembalikan nilainilai spiritual yang telah terkikis oleh pemikiran modern, sejarah sesuci yang mempunyai akulturasi budaya dalam setiap metode dan maknanya menandakan setiap agama yang terakulturasi dalam tradisi sesuci mempunyai kebenaran universal tentang eksistensi alam. Selain itu tuduhan syirik terhadap tradisi sesuci menandakan bahwa masyarkat modern hanya mementingkan simbol-simbol agama dan telah melupakan esensi dan nilai-nilai esoteris dari sebuah agama termasuk melupakan unsur-unsur ekologis yang terdapat dalam agama. Alam mempunyai peran besar tidak hanya dalam perjalanan hidup manusia, tetapi alam juga merupakan 'tanda' (āyah) untuk memahami Tuhan, hal inilah yang telah dilupakan oleh masyarakat modern sehingga tradisi sesuci mencoba meletakkan kembali alam sebagai àyah Tuhan yang perlu dikagumi.

\section{Daftar Rujukan}

Adian, Donny Gahral. Martin Heidegger. Jakarta: Teraju, 2003

Anonim. Wawancara. Desa Srigading, 10 November 2017. 
Danandjaja, James. Folklor Indonesia: Ilmu Gosip, Dongeng, dan Lain-lain. Jakarta: Pustaka Utama Grafiti, t.th.

Dewi, Saras. Ekofenomenologi: Mengurai Disekuilibrium Relasi Manusia dengan Alam. Tangerang Selatan: Marjin Kiri, 2017.

Eliade, Mircea. The Sacred and the Profane: The Nature of Religion, translated from the French by Wlliard R. Trask. New York: Harcourt, Brace World, 1959.

Endraswara, Suwardi. Agama Jawa: Ajaran, Amalan, dan Asal-usul Kejawen. Jakarta: Narasi, 2017.

Endraswara. Mistik Kejawen: Inkretisme, Simbolisme, dan Sufisme dalam Budaya Spiritual Jawa. Yogyakarta: Narasi 2017.

Geertz, Clifford. Agama Jawa: Abangan, Santri, Priyayi dalam Kebudayaan Jawa, terj. Aswab Mahasin dan Bur Rasuanto. Depok: Komunitas Bambu, 2014.

Izutsu, Toshihiko. God and Man in The Qur'an: Semantics of the Qur'anic Weltanschaunng. Kuala Lumpur: Islamic Book Trust, 2004.

Kieven, Lydia. Following the Cap-Figure in Majapabit Temple Reliefs: A New Look the Religious Function of East Javanese Temples, 14th and 15th Centuries. Leiden: Brill, 2013.

Maimun, Ach. Seyyed Hossein Nasr: Pergulatan Sains dan Spiritualitas Menuju Paradigma Kosmologi Alternatif. Yogyakarta: Ircisod, 2015.

Muljana, Slamet. Menuju Puncak Kemegahan: Sejarah Kerajaan Majapahit. Yogyakarta: LKiS, 2012.

Mulyadi, Wawancara, Candi Jolotundo, 14 November 2017.

Muntahari, Murtadha. Falsafah Agama dan Kemanusiaan: Perspektif alQur'an dan Rasionalisme Islam. Yogyakarta: Rausyan Fikr, 2013.

Nasr, Seyyed Hossein. Knowledge and Sacred. New York: State University of New York Press, 1989.

Nugroho, Ito Prajna. Fenomenologi Politik: Membongkar Politik Menyelami Manusia. Purworejo: Sanggar Pembebasan Pancasila, 2013.

Riyadi, Abdul Kadir. Antropologi Tasawnf: Wacana Manusia Spiritual dan Pengetahuan. Jakarta: LP3ES, 2014.

Salam. Wawancara. Balai Desa Seloliman, 13 November 2017.

Simuh. Mistik Islam Kejawen Raden Ngabebi Ranggawarsita: Suatu Studi terhadap Serat Wirid Hidayat Jati. Jakarta: UI-Press, 1988.

Teguh. Wawancara, Trawas, 13 September 2017.

Wagenfuhr, Gregory. "Postmodernity, the Phenomenal Mistake: Myth and Environment," Philosophy of Engineering and Technology, Vol. 13, 2013. 
Tinjauan Ekoteologi Relasi Manusia dan Alam

Yoyok. Wawancara. Tunjung Sari, 24 Juli 2017. 